\title{
Reveal the "Face" of the Impartiality in the Indonesian Criminal Justice System: Challenges and Development
}

\author{
I Made Sukanada ${ }^{1}$, Slamet Sampurno ${ }^{2}$, Syamsuddin Muchtar $^{3}$, Nur Azisa $^{4}$ \\ \{imadesukanada16@gmail.com\} \\ Graduate School, Hasanuddin University; District Court of Kendari, Sulawesi Tenggara, Indonesia \\ Faculty of Law, Hasanuddin University, Indonesia ${ }^{2}$
}

\begin{abstract}
An impartial legal process is one of the characteristics of a rule of law. Likewise, Indonesia, in criminal justice at its downstream is played by judges as the core apparatus of judicial power, the principle of freedom and impartiality of judges in examining, hearing and deciding cases. The research is a normative legal research using statute, case, comparative and conceptual approaches. Data were analyzed with descriptive qualitative analysis with content analysis. The results show that the essence of the principle of impartiality in the criminal justice system is closely related to the implementation of the function of judicial power. Fair trials are a most basic safeguard to ensure that individuals are not punished unfairly. However, research shows that the application of the principle of impartiality in the practice of law enforcement that is currently just in a number of cases is still colored by the practice of wrongful arrests which lead to wrong arrests and wrong sentences (error in personal).
\end{abstract}

Keywords: Criminal Law; Error in Personal; Impartiality; Judicial Power

\section{Introduction}

The concept of a constitutional State shows that all elements in exercising any action must be based on accountable law [1]. The policy towards optimal law enforcement is crucial thing and has a great effect in realizing a just law. It is based on the consequences of the embodiment of the rule of law concept, where everything must be based on law and also provide legal certainty. The embodiment of law enforcement in a proportional manner must be supported by an optimal judicial system as an important component in achieving legal objectives [2]. Legal development refers to increasing legal awareness, services and legal certainty as well as realizing a legal order that serves and it is oriented towards the national interest. At the same time, it provides an answer that legal development must lead to the formation of a legal system that originates from the socio-culture of a nation. Taking into account these matters, in the development of a just law, it is necessary to run the legal system optimally through the integration of legal instruments, legal culture, and law enforcement actors as the front guard in law enforcement.

The principle of impartiality as the main issue of this research contains a "humanist" meaning, it is reflected in an inner attitude and outlook on life that glorifies individual rights, treats all people equally, fair and not have prejudice against others. The word impartial comes from the English language "impartiality" which means fair treatment, and then it is translated into Indonesian, which is almost same as the pronunciation of the original [3]. Impartiality is a 
mandate used to defend victims of human rights violations. It does not differentiate between origins, social strata, race, religion or political [4].

In relation with the existence of juridical problems in the form of vague of norms and vacuum of norms, this is the basis for researchers to test and conduct further research on this legal issue. In addition, the challenge of the impartiality of the judicial power in the criminal justice system is still colored by classic problems including issues related to public pressure, trial by the press, cultural aspects, patron relations, physical and psychological threats to the judicial apparatus, in the midst of the absence of immunity right for the position of judge, up to contempt of court instruments and an adequate security system.

On this basis, the principle of impartiality of judicial power in the criminal justice system needs to be studied descriptively and analytically with a philosophical approach in order to design an independent judicial power as mandated by the constitution. This effort must be made, so that the goal of establishing a criminal justice system which is expected to be a means of upholding law and justice can be realized, so that actions that injure the sense of justice do not occur, such as cases of wrong arrest which lead to wrong verdicts (error in persona).

Treatments in punishment must always be closely related to the implementation of the principle of impartiality or referred to in the principles of impartiality. Likewise, that the principle of impartiality is not only applied to suspects or defendants, impartiality must be interpreted including the treatment of crown witnesses, victim witnesses and their families and also cannot be ignored regarding the existence of society as legal subjects who have an interest in the implementation of public law. Furthermore, the structure of social life is unlikely to succeed if it is not accompanied by law development and law enforcement.

Depart from the construction of these legal issues; there is a gap between the desire and the reality of the implementation of the principle of impartiality in the realm of law enforcement. Therefore, the researcher focuses on the juridical-philosophical aspects of the nature of the principle of impartiality in a criminal justice system.

\section{Research Methods}

The research is a normative legal research using Statute, Case, Comparative and Conceptual approaches [5] Data were analyzed with descriptive qualitative analysis with content analysis. The approach used is observation and interpretation, which makes these phenomena observable [6]. This paper provides information on the latest trend in research [7].

\section{Results and Discussion}

\subsection{Error in Persona in Law Enforcement Practices: Criminal Law Policy}

Epistemologically, the way to apply the principle of impartiality of judges through the judge' conviction, comes from the conscience of the judge. It cannot be denied that the conviction which comes from the conscience of the judge sometimes cannot be applied consequently due to the belief that grows in the conscience of the judge, must come from at least 2 (two) valid evidence. Obtaining two valid evidence is started with the collection of valid evidence by the investigator. 
Impartiality is more likely to be used in the field of law, but in its development, the term impartial is also widely used in various aspects of life. On another understanding, the meaning of impartiality is a view of life that glorifies individual rights (without prejudice to communal rights). Thus, the principle of impartiality treats all people equally is fair and does not have prejudice against others, has the character of paying attention to people who are less fortunate or victims of human rights violations. Impartiality can also mean as an order to provide protection for human rights. This principle is a very basic principle and should be used as a basis for law enforcement [8].

Although the principles of human rights are contained in Indonesian Criminal Law, not a few criticisms are directed in the current practice of criminal law enforcement, including in cases of wrongful arrest (error in persona). Its main criticism is aimed at the claim that the orientation of criminal law is merely upholding the law, upholding the rules, not upholding justice. The current criminal justice process shows the blurred orientation of law enforcers between efforts to uphold the law and uphold justice. The main objective in litigating is not to uphold law and justice, but to win cases.

The shift in the orientation of law enforcers in criminal justice which emphasizes more pragmatic rationality, distorts the moral ethical values of law enforcement and justice, is then diverted to also relate to juridical conceptual problems. The legal positivism paradigm that characterizes modern law, puts forward the function of statutory regulations, tends to be tied to the formalism and procedural of statutory regulations, and does not dig up substantial valuesfrom the law, so that it raises sharp criticism. Criticism of the character of modern law is how to get out of blind formalism and how to reconcile the principle of legal legality with morality [9].

The concept of law as a legal text in its application departs from a methodological syllogism, structured in a deductive-logical syllogism, so that the subjectivity of ethical values is trapped in a logical-deductive logic. Court decisions are no more as a result of conclusions from deduction of legal texts to concrete events in a case, so that fair and unfair considerations are very relative, because judges' legal arguments end in deductive logical conclusions that emphasize legal certainty, ignore moral values justice [10] The judiciary should carry out a social function, by mobilizing the court to solve community problems, not merely applying laws that emphasize legal certainty [11].

As already mentioned above, that the principle of impartiality in the criminal justice system at the stage of investigation, pre-prosecution, prosecution before the judge' verdict is passed is side by side with the principle of presumption of innocence and the principle of due process of law. However, in reality, there are often deviant practices in the implementation. In several cases studied, the practice of investigation, investigation and prosecution actually adheres to prejudice as if the suspect/ defendant is the perpetrator of a criminal act, this clearly violates the provisions of the Criminal Code, especially the procedural law of evidence before a sentence is passed so that often investigations suspect, detain, accuse and convict people even though they are not the perpetrators of a criminal act (error in persona).

Error in persona in a number of cases above shows inaccuracy, carelessness in implementing procedural law in law enforcement practices. So that it has led to the violation of the human rights of the suspect/defendant. Law enforcement errors generally arise from assumptions or allegations of criminal acts that only adhere to "preliminary evidence" as article 17 of the Criminal Procedure Code "An arrest warrant is made against a person who is strongly suspected of committing a criminal act based on sufficient preliminary evidence", vide Article 1 point (14) Criminal Code" a suspect is a person who due to his actions or circumstances based on preliminary evidence is reasonably suspected of being the perpetrator 
of a criminal act. Wrong arrest accompanied by violence during investigation has tarnished the image of law enforcers. In fact, international law prohibits torture and other ill-treatment under all circumstances [12]. International standards also require that no person accused of a criminal offense can be forced to admit guilt or testify against them.

The results of research showed that in the case of error in persona, all suspects or defendants were accompanied by a lawyer. These attorneys assisted them from the time they became suspects until they were convicted or not guilty by the court. However, in practice, there are many criminal cases where the suspect or defendant does not receive legal assistance. Even though it is a right, in practice, the right to get legal assistance still depends on the willingness of the suspect or defendant. Consequently, without being accompanied by a legal advisor, it does not obstruct the proceedings of the investigation of the suspect or defendant. It is different if the quality of obtaining legal assistance is mandatory.

Apart from being an option for the suspect/defendant whether to exercise his right to obtain legal assistance or not, the criminal procedure law also limits access to legal aid only in cases where the threat is 5 years or more. Article 56 paragraph 1 Criminal Code reads:

In the case that a suspect or defendant is suspected or charged with committing a criminal offense punishable by death penalty or imprisonment for fifteen years or more or for those who are incapacitated who are liable to imprisonment of five years or more who do not have their own legal advisor, the officials concerned in all the level of examination in the judicial process shall appoint legal advisors for them.

It means that in cases with a threat of less than five years, legal assistance is not required or in another sense the suspect/defendant can seek legal assistance by himself. However, in practice it has been found, for criminal cases where the threat is less than five years, investigators or prosecutors are reluctant to convey this or obstruct access to legal assistance to the suspect/defendant on the grounds that if the suspect/defendant is accompanied by a legal advisor/lawyer then the legal process will be carried out to be long.

Another case, in the provision of legal assistance is that there is still no structural synchronization between law enforcement officials in terms of the provision of legal assistance, especially in the context of criminal justice. The presence of legal advisers who should have started at the beginning of the examination or investigation is often ignored by investigators. Therefore, it is not uncommon for a suspect to be examined by investigators without being accompanied by a legal advisor. Investigators are not fully aware that the presence of a legal advisor/lawyer is a procedural requirement for the realization of a fair and honest trial. In fact, some investigators think that the presence of legal advisors/lawyer in the investigation or investigation process will hamper the smooth running of the investigation process.

One of the rights of suspects that are often questioned is the right to choose to answer or not to answer questions raised by investigators, public prosecutors and judges. What is at issue at the investigation level is whether the suspect has the right to answer questions from the investigator. In England the right not to reply applies, even very strictly. The examiner must start by telling the "suspect" that he has the right to remain silent, not answering questions [13].

According to international standards, everyone who is detained or charged with a criminal offense has the right to advice during detention, in court and on appeal. Principle 1 of the UNs Basic Principles on the role of a lawyer [14] states that:

Everyone has the right to have the assistance of a lawyer of their own choice, to protect and guarantee their rights and defend them at all levels of the criminal process." International standards state that when a person is arrested or accused of a criminal offense 
and does not have a defender of his own choosing; they are entitled to have a lawyer appointed by a judge or judicial authority, whenever court interests are required. If the person is unable to pay, a designated defender must be provided free of charge [15] Whether the court' interest requires it depends fundamentally on the seriousness of the offense, the severity of the potential penalty, and the complexity of the issues involved in the case.

As a right, legal assistance to the perpetrator of a criminal act should be given in full since the investigation stage where the person concerned is determined to be a suspect in the criminal act. Criminal procedural law must not limit the obligation to obtain legal assistance to criminal cases with a threat of five years or more, because if so, then the legal consequences can trigger things as follows. The first, violating rights, legal assistance is a right provided by laws and regulations and international human rights conventions. As a right, it should not be limited by the limitations of the criminal threat. Positive law must give that right in full.

The second, if restricted by the criminal threat, it is feared that the rights of the suspect/defendant to fight for their legal interests in accordance with the presumption of innocence will be hampered. Many criminals do not understand that legal aid is something they are entitled to. So that legal assistance provided by an attorney/lawyer is able to protect his legal rights as a suspect/defendant/convicted.

The third, to protect the legal rights of suspects/defendants from the subjectivity of investigators and prosecutors, even though the suspect/defendant is protected by the presumption of innocence until the verdict is legally binding (in kracht van gewijsde), there is still the potential for his legal rights to be violated at the stage of investigation and prosecution. It is not uncommon to hear of the practice of violence, both physical and psychological, that a suspect/defendant has received at the stage of investigation or prosecution, including the blessing of the legal process he has been undergoing while he is in detention, who do not have a certain time when the case will be transferred to prosecution for trial.

The fourth, there is no an opportunity to present a mitigating witness. There is no legal assistance provided also did not allow the suspect/defendant to present a witness to mitigate himself during the investigation and trial of evidence. In fact, witness testimony that mitigates it is very important to defend his legal interests. This is of course contrary to international standards in the ICCPR, where according to international standards, all persons charged with committing a crime have the right to summon witnesses on their behalf, and to examine or have examined their witnesses [16].

Detention at every stage is also a serious problem to be faced. There were often "extended" detentions because the police were still gathering evidence or at the prosecutor's office, detention was extended for certain reasons [17]. Whereas it should have been, when someone was declared a suspect, the investigator had already pocketed "two evidence" so it did not take a long time to be transferred to the prosecution hearing. Likewise, at the Prosecutor Office, if the files from the investigators are complete, there is no need to delay to immediately transfer the case to the court. The length of detention due to this situation has violated the suspect/defendant' right to immediately obtain legal certainty for the case he is experiencing.

The right to obtain legal assistance is a basic or basic right for someone who is affected by legal problems. Because obtaining legal assistance is a form of access to justice for those who are or are dealing with legal problems. Obtaining legal assistance is also a manifestation of equality before the law. The principle of equality before the law has been contained in Article 28D paragraph (1) of the 1945 Constitution, namely that everyone has the right to recognition, guarantees, protection, and legal certainty that is just and equal treatment before 
the law. This is a consequence of Indonesia being a constitutional state (Article 1 paragraph (3) of the 1945 Constitution). There are three principles of rule of law (rechstaat), namely the supremacy of law, equality before the law, and law enforcement in ways that are not against the law (due process of law) [18]. Provisions for obtaining legal assistance are also contained in Article 56 paragraph (1) of Act No. 4 of 2009 concerning Judicial Power that everyone involved in a case has the right to obtain legal assistance.

Provision of legal assistance is a means of support for law enforcement in general and an effort to protect human rights from arbitrary actions by law enforcers. Law enforcement (criminal) apparatus are part of the structure of criminal law, so that no matter how perfect the substance of criminal law is without law enforcement, there is no benefit in realizing the objectives of the criminal justice system. The substance of legal aid in Indonesia becomes the most fundamental question, namely whether legal aid is compulsory or only obligatory after certain conditions are met. Legal aid is an important instrument in the Criminal Justice System because it is part of the protection of human rights, particularly the right to freedom and the right to body and soul of the suspect/defendant [19].

The rights of suspects can be developed, either through laws, court decisions (jurisprudence) and good methods of law enforcement. According to Mardjono, the principles mentioned above are part of a correct understanding of the due process of law, one of which is that the suspect and the defendant must be given guarantees to be able to defend themselves fully. How a suspect can best defend himself during questioning by investigators when he is not clearly informed of the reasons for his arrest. This principle also explains why legal advisers from the time of arrest have the right to see the case files prepared by the investigator as the basis for filing a case with the prosecutor.

The legal assistance to citizens is an effort to fulfill and at the same time implement a rule of law that recognizes and protects and guarantees the human rights of citizens regarding the need for access to justice and equality before the law. The guarantee of this constitutional right has not received adequate attention.

\subsection{Strengthening the principle of impartiality through the instrument of the code of ethics for law enforcers}

Apart from still containing deficiencies in articles that have been presented above, if we examine the Criminal Procedure Code which consists of 286 Articles, we do not find the word "impartial". Whereas the Criminal Procedure Code regulates many matters regarding criminal procedure law which is enforced by the police, prosecutors and judges as a procedural law that serves as a guideline for action for law enforcement officials, it is very important to include impartial principles in the Criminal Procedure Code. Therefore, there is no abuse of authority that exceeds the limit.

The process of investigation, pre-prosecution, prosecution and judge' verdict is a series of criminal procedure laws which are also closely related to protecting the human rights of a criminal suspect/defendant. Before the case has permanent legal certainty (in kracht van gewijsde), then every suspect/defendant has legal rights that must be protected, the law must not be discriminatory, either from a personal perspective or to limit the provision of legal assistance as mentioned above.

The case of wrong arrest which resulted in a wrong verdict (error in persona), as discussed on the previous page, is the fruit of a formal and material flawed investigation and prosecution process. This is because at that stage, the investigator or prosecutor often builds a prejudice that the suspect is believed to be the perpetrator of a crime, even though it has not been through a process of proof in a balanced and fair trial (fair trial). Prejudice is subjective 
in nature and is usually influenced by legal and non-legal factors. Legal factors, for example the suspect is a recidivist, the suspect is deemed to have lost evidence or dodged the emotion of the investigator. Meanwhile, non-legal factors, for example the investigator recognize the suspect as a bad person, or the case has become the media's coverage of widespread attention.

The dignity or identity of a professional organization will also be determined by the quality of empowering the professional code of ethics of the organization itself. With a code of ethics, it is not only clients whose rights can be articulated, but the interests of the state in general can also be protected. The professional code of ethics becomes a reference so that members of the profession remain dignified in their profession. With this code of ethics, a profession that is carried out will avoid wild communities and interactions and tend to tolerate various ways of violating norms.

In order to avoid deviations from carrying out the profession, especially the legal profession, a norm is established which must be obeyed by people who are members of a profession commonly known as "Professional Ethics". With the hope that these professionals submit and comply with the code of ethics of their profession, even though they already have a professional code of ethics, there are still many cases of error in persona in law enforcement practices that occur showing deficiencies in the substance of the content material and the implementation of the professional code of ethics itself. It is realized that the integrity of the personality of a law enforcer is more important. However, the integrity of that personality must be bound and contained in a code of ethics that becomes a code of conduct in carrying out his duties and powers.

If studying a number of legal profession codes of ethics above, one of the shortcomings is found is that it does not include the word "impartiality" and "upholds the presumption of innocence" in carrying out the legal profession. This is certainly dangerous in practice as reviewed above. So that if it is not balanced with the application of the principle of impartiality, this authority can lead to violation of the rights of the suspect/defendant, therefore the criminal procedure law regulates the procedures for the use of authority at each stage so as not to deviate from the Criminal Procedure Code and violate the human rights inherent in a suspect/defendant.

Here it is important to include and strengthen the principle of impartiality in the legal profession code of ethics. Along with the presumption of innocence and the principle of due process of law, if the principle of presumption of innocence is more about protecting the rights of the suspect/defendant, impartiality is more about limiting the authority of investigators and prosecutors so as not to deviate from the Criminal Procedure Code. Such as when carrying out interrogation, arrests and detention, this impartial limitation is not a barrier for investigators and prosecutors, but so that investigators and prosecutors remain neutral and objective in handling a criminal case.

This is important so that every case submitted to the prosecution trial is not formally and materially flawed which results in the acquittal of the defendant because the judge believes there is insufficient evidence to find the defendant guilty. The application of the principle of impartiality at the stage of investigation and prosecution also helps investigators and prosecutors to become more professional in investigating every criminal case.

Also, in this code of conduct the principle of impartiality is in line with international standards (ICCPR). According to international standards, everyone who is arrested or detained has the right to be informed in a language he knows, of the following: The person concerned must be immediately informed of the reasons why he was deprived of his liberty. The person concerned should be immediately informed of what charges are being brought against him. 
The person concerned must be informed of his/her right to be explained how he or she uses these rights.

These requirements are intended to ensure that persons who are arrested or detained have access to the necessary information, to question the legality of their detention, and to exercise their rights under the law. The requirement also requires anyone who faces trial on criminal charges, whether he is detained or not, to begin preparations for his own defense [20]. In line with the presumption of innocence, is that a detainee, suspect or accused must be treated according to this right at all stages of the process prior to confirmation of a final decision. Judges, prosecutors, police and all other public authorities must refrain from making statements about the guilt or innocence of an accused, before a trial can result [21].

This is in line with one of the principles in criminal law, "geen straf zonder schuld" which means "there is no crime without error". A person can only be punished for his actions that violate the law if there is an error against him. Mistakes are a fundamental element in criminal law. Criminal responsibility must meet the elements of mens rea and actus reus so that the perpetrator is subject to punishment. Mens rea is the inner attitude (evil intention) of the criminal. In contrast to the actus reus which deals with unlawful acts, mens rea includes elements that make a criminal act, namely an inner attitude which is called the subjective element of a criminal act or the psychological state of the maker [22]. It is a crime to impose criminal responsibility on a person accused of committing a crime but who did not actually commit it. It is better to acquit a thousand guilty people than to punish one innocent person

\section{Conclusion}

Currently, the essence of the principle of impartiality in the criminal justice system is closely related to the implementation of the function of judicial power. Fair trials are a most basic safeguard to ensure that individuals are not punished unfairly. Impartiality and due process of law rests on the universal human rights doctrine, that there are 3 (three) main principles in the normative view of human rights, i.e universally applicable, nondiscrimination and impartial. Impartiality, neutrality and an attitude without bias and prejudice in examining, hearing and deciding cases, it is aimed at preventing conflicts of interest, taking sides, and maintaining the honor and authority of the court.

However, research shows that the application of the principle of impartiality in the practice of law enforcement that is currently just in a number of cases is still colored by the practice of wrongful arrests which lead to wrong arrests and wrong sentences (error in persona).

\section{References}

[1] Esther van Ginneken and David Hayes. 2017. "'Just' punishment? Offenders' views on the meaning and severity of punishment." Criminology \& Criminal Justice Vol. 17, No. 1: 62-78.

[2] Hamdorf, Kai. 2007. "The concept of a joint criminal enterprise and domestic modes of liability for parties to a crime: a comparison of German and English law." Journal of International Criminal Justice, Vol. 5, No. 1: 208-226.

[3] Human Rights Committee, General Commentary 13, Article 14 (Part twenty-first, 1984), Compilation of General Comments and General Recommendations Adopted by Human Rights Treaty Bodies, UN Doc. HRI GEN $\backslash 1 \backslash$ Rev.1 at 14 (1994), p. 7. 
[4] Irwansyah. 2020. Penelitian Hukum: Pilihan Pendekatan dan Praktik Penulisan Artikel,. Yogyakarta: Mirra Buana Media.

[5] Keng, Shao-Hsun. 2017. Handout Research Topic Development, Collage of Management, National University of Kaohsiung, Taiwan.

[6] M. Syamsudin, 2010. "Faktor-Faktor Sosio-legal yang Menentukan Dalam penanganan Perkara Korupsi di Pengadilan", Jurnal Media Hukum; 3(1).

[7] Maya Indah S, 2008. "Refleksi sosial atas Kelemahan hukum Modern,suatu diseminasi hukum tradional dalam citra hukum Indonesia", Jurnal Masalah-Masalah Hukum, Fakultas Hukum Universitas Diponegoro, Semarang, Vol 103 No. 37, p. 164.

[8] Nahak, Simon. 2017. "Criminal law policy on land functions impacting climate change in Indonesian national law perspective." International Journal of Social Sciences and Humanities, Vol. 1, No. 3: 28-39.

[9] Ni Nengah Adiyaryani. 2017. Asas Independensi dan Imparsialitas Hakim Menurut Sistem Peradilan Pidana. Malang: Program Pascasarjana, Universitas Brawijaya.

[10] Rifai, E. 2010, "Peran Hakim Dalam Penemuan Hukum dan Menciptakan Hukum Pada Era Reformasi”, Jurnal Ilmu Hukum "Praevia". Vol. 4. No. 1: 49.

[11] Rima, F. 2019. "Fatamorgana Keadilan Hukum Dalam Prinsip the Rule of Law." Pergulatan Etika Indonesia, Jakarta: Seri Filsafat Atmajaya.

[12] Roth, Wolff-Michael. 2015. Rigorous Data Analysis, beyond “Anything Goes”, Sense Publishers, Taipei.

[13] Santosa and Asfnawati, 2007. Bantuan Hukum Akses Masyarakat Marjinal Terhadap Keadilan Tinjauan Sejarah, Konsep, Kebijakan, Penerapan dan Perbandingan Di Berbagai Negara, Jakarta: LBH Jakarta. 